\title{
Prospektiv og retrospektiv
}

\author{
I prospektive studier følges deltakerne fremover i tid. I retrospektive studier ser man tilbake.
}

I helseforskningen skiller vi mellom eksperimentelle studier, der forskerne selv foretar intervensjoner under mer eller mindre kontrollerte forhold, og observasjonelle studier, der forskerne observerer og analyserer det som skjer uten selv å interagere med virkeligheten. Begrepene «prospektiv» og «retrospektiv» er særlig knyttet til observasjonelle studier.

\section{Å se fremover og bakover}

Rent språklig kommer begge begrepene fra latin. Prospektiv betyr fremoverskuende (å se fremover) og retrospektiv betyr bakoverskuende (å se bakover). Fremover og bakover har i denne forbindelse altså med tid å gjøre.

Det oppstår av og til forvirring rundt disse begrepene. Årsaken er at de brukes litt forskjellig i dagligtale og i forskning. I folkelig tale forholder de to begrepene seg til vår egen plassering i tid. Vi sier at det som skal skje fremover, er prospektivt, mens det som har skjedd, er retrospektivt (1).

For å skille mellom prospektivt og retrospektivt i forskningen, må man ta utgangspunkt i når forskningsdeltakerne inkluderes i studien i forhold til utfallsmålet (f.eks. funksjonsnivå, diagnose, død). Skjer inklusjonen før og deltakerne følges frem til utfallsmålet, er det en prospektiv studie. Skjer inklusjonen etter at utfallsmålet er nådd og man studerer forhistorien, er det en retrospektiv studie. Sagt på en annen måte: En prospektiv studie svarer på spørsmålet «Hva kommer til å skje?», en retrospektiv studie svarer på spørsmålet «Hvorfor skjedde det?». Forvirringen bør kunne unngås hvis man holder fast på at tidsangivelsene forholder seg til årsak-virkning-relasjonen (1).

En typisk prospektiv studie er en kohortstudie der man over et tidsrom etter inklusjonen følger en gruppe mennesker som har vært, blir eller vil bli utsatt for eksponering for en faktor som kan påvirke helsetilstanden. Et klassisk eksempel er The British Doctors' Study, der man inkluderte over 30000 britiske leger som ble fulgt fra 1951 til 2011. I denne studien ble sammenhengen mellom røyking og overdødelighet, særlig av lungekreft, vist (2).

Et eksempel på en retrospektiv studie er en pasient-kontroll-studie (case-control study) der fortiden til personer med en sykdom eller et symptom sammenlignes med fortiden til personer uten den samme tilstanden - med tanke på å avdekke ulikheter. Forløperen til The British Doctors' Study var nettopp en slik studie, der sir Richard Doll (1912-2005) og sir Austin Bradford Hill (1897-1991) tok utgangspunkt i pasienter med lungekreft og fant at disse hadde hatt et større tobakksforbruk og av lengre varighet enn pasienter uten lungekreft (3).

\section{Beskrivelse er bedre enn begreper}

Dessverre brukes begrepene prospektiv og retrospektiv iblant på ulike og uklare måter i forskningssammenheng (4). Når deltakerne $i$ en tverrsnittsundersøkelse rekrutteres fortløpende, gjør ikke det studien prospektiv, selv om det av og til omtales slik. Det er også uheldig at begrepet «retrospektiv kohort» har fått fotfeste i forskningsterminologien. Et søk i PubMed gir nesten 30000 treff på «retrospective cohort» (4.3.2016).

Når en kohort rekonstrueres på bakgrunn av dokumentasjon som ligger tilbake i tid, er det bedre å betegne studien som en historisk kohortstudie $(5,6)$. Da unngår man sammenblanding med retrospektiv i den vanlige betydningen, nemlig pasient-kontroll-studie (6). Hvorvidt forskningsdeltakerne følges fremover eller bakover i tid, bør være avgjørende for om studien betegnes som prospektiv eller retrospektiv.

Problemstillingen har vært drøftet i Tidsskriftet tidligere (6-8), men forvirringen synes å øke. Det minner oss om at betydningen og forståelsen av ord og begreper kan endres over tid. Begrepsforvirringen viser også hvor viktig en grundig og detaljert metodebeskrivelse er. Det er viktigere å beskrive hvordan en studie er designet enn å benytte enkle merkelapper som kan tolkes ulikt både av forfattere og lesere.

\section{Magne Nylenna}

magne.nylenna@fhi.no

Magne Nylenna (f. 1952) er direktør for Kunnskapssenteret i Folkehelseinstituttet og professor II i samfunnsmedisin ved Universitetet i Oslo.

Litteratur

1. Bakketeig LS, Magnus P. Epidemiologi. 2. utg Oslo: Ad Notam Gyldendal, 2000: 25-6.

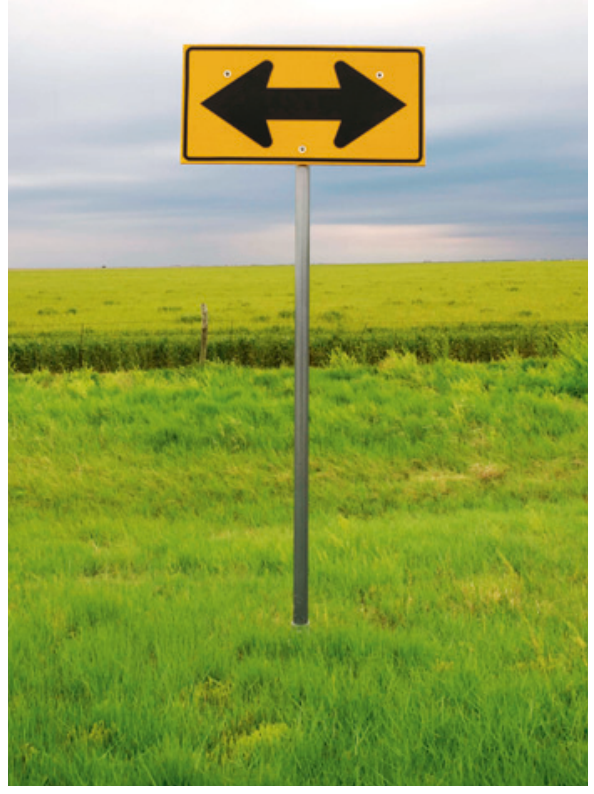

Hvorvidt forskningsdeltakerne inkluderes i en studie før eller etter utfallsmålet, er det som avgjør om studien er prospektiveller retrospektiv. Illustrasjonsfoto: Thinkstock

2. Doll R, Peto R, Boreham J et al. Mortality in relation to smoking: 50 years' observations on male British doctors. BMJ 2004; 328: 1519-33.

3. Doll R, Hill AB. Smoking and carcinoma of the lung; preliminary report. BMJ 1950; 2: 739-48.

4. Thelle DS. Epidemiology. A basis for public health and disease prevention. Oslo: Gyldendal Akademisk, 2015: 62

5. Porta M, red. A dictionary of epidemiology. 6. utg Oxford: Oxford University Press, 2014.

6. Jacobsen G. Analytisk epidemiologi - pasient-kontroll- og kohortstudier. Tidsskr Nor Lægeforen 2002: 122: $2636-40$

7. Saad E. Analytisk epidemiologi - pasient-kontrollog kohortstudier. Tidsskr Nor Lægeforen 2003; 123: 212-3

8. Jacobsen SE. Tilsvar: Analytisk epidemiologi pasient-kontroll- og kohortstudier. Tidsskr Nor Lægeforen 2003; 123: 213. 